\title{
HUBUNGAN ANTARA KECERDASAN EMOSIONAL DAN KETERAMPILAN METAKOGNITIF TERHADAP HASIL BELAJAR SISWA KELAS VII SMP NEGERI DI KABUPATEN NUNUKAN
}

\section{The Correlation Between Emotional Intelligence And Metacognitive Skills On Learning Outcome Of VII Grade Students of Public Junior High Schools In Nunukan Regency}

\author{
Dini Andini Poetri ${ }^{\mathrm{a}}$, Endik Deni Nugroho ${ }^{\mathrm{a}^{*}}$, Vlorensius $^{\mathrm{a}}$
}

a Program Studi Pendidikan Biologi/Pendidikan Biologi/Universitas Borneo Tarakan, Tarakan, Kalimantan Utara, Indonesia ${ }^{*}$ Corresponding author: J1. Amal Lama, Tarakan Timur, Tarakan, Kalimantan Utara, 77123, Indonesia. E-mail:endwi.2011@ gmail.com

\begin{abstract}
Abstrak
Kecerdasan emosional merupakan kemampuan siswa dalam mengenali dan mengontrol emosi diri, sehingga berdampak positif pada saat mengikuti pembelajaran. Kecerdasan emosional erat kaitannya dengan keterampilan metakognitif. Keterampilan metakognitif adalah kemampuan siswa untuk mengontrol proses belajarnya, mulai dari tahap perencanaan, memilih strategi yang tepat sesuai masalah yang dihadapi kemudian melihat kemajuan dalam belajar dan mengoreksi jika terjadi kesalahan. Penelitian ini bertujuan untuk menganalisis hubungan antara kecerdasan emosional terhadap hasil belajar siswa dan menganalisis hubungan antara keterampilan metakognitif terhadap hasil belajar siswa. Jenis penelitian ini adalah penelitian survey dengan menggunakan metode deskriptif korelasional. Populasi dalam penelitian ini adalah 920 siswa kelas VII seluruh SMP Negeri di Kabupaten Nunukan dan sampel penelitian adalah 242 siswa dengan penentuan sampel menggunakan rumus Nomogram Harry King. Keseluruhan data diperoleh berdasarkan skor dari angket kecerdasan emosional, tes essai keterampilan metakognitif, dan tes pilihan ganda hasil belajar siswa. Kemudian, data dianalisis dengan uji korelasi Pearson Product Moment. Hasil penelitian menunjukkan bahwa kecerdasan emosional memiliki korelasi terhadap hasil belajar siswa sebesar 0,122 yang berarti kecerdasan emosional tidak memiliki hubungan terhadap hasil belajar siswa. Disamping itu, keterampilan metakognitif memiliki korelasi terhadap hasil belajar siswa sebesar 0,029 yang berarti keterampilan metakognitif memiliki hubungan terhadap hasil belajar siswa. Sumbangan efektif kecerdasan emosional terhadap hasil belajar sebesar $0,9 \%$ dan sumbangan relatifnya $34 \%$. Selanjutnya, sumbangan efektif keterampilan metakognitif terhadap hasil belajar sebesar $1,3 \%$ dan sumbangan relatifnya $48 \%$.
\end{abstract}

Kata kunci: Kecerdasan emosional, Metakognitif, hasil belajar 
Emotional intelligence is the ability of students to recognize and control their own emotions, so that they have a positive impact when participating in learning. Emotional intelligence is closely related to metacognitive skills. Metacognitive skills are students' abilities to control the learning process, starting from the planning stage, choosing the right strategy according to the problem at hand, then seeing progress in learning and correcting if something goes wrong. This study aims to analyze the relationship between emotional intelligence and student learning outcomes and to analyze the relationship between metacognitive skills and student learning outcomes. This type of research is survey research using descriptive correlational methods. The population in this study were 920 grade VII students of all state junior high schools in Nunukan and the study sample was 242 students with the determination of the sample using the Harry King Nomogram formula. Overall data were obtained based on scores from emotional intelligence questionnaires, metacognitive skills essay tests, and multiple choice tests of student learning outcomes. Then, the data were analyzed by using Pearson Product Moment correlation test. The results showed that emotional intelligence has a correlation with student learning outcomes of 0.122 which means that emotional intelligence has no relationship with student learning outcomes. In addition, metacognitive skills have a correlation with student learning outcomes of 0.029, which means that metacognitive skills have a relationship with student learning outcomes. The effective contribution of emotional intelligence to learning outcomes is $0.9 \%$ and the relative contribution is $34 \%$. Furthermore, the effective contribution of metacognitive skills to learning outcomes was $1.3 \%$ and the relative contribution was $48 \%$.

Kata kunci: Emotional intelligence, Metacognitive, learning outcomes

\section{Pendahuluan}

Kemampuan siswa dalam belajar seringkali dikaitkan dengan kemampuanintelektualnya. Pengukuran kemampuan intelektual ini ditunjukkan oleh hasil tes IQ (Intellegence Quotient) atau kecerdasan intelektual. Siswa dengan kecerdasan intelektual diatas rata- rata atau bahkan tinggi, tidak menunjukkan prestasi yang memuaskan sesuai dengan kemampuannya dalam belajar. Seringkali ditemukan siswa yang mendapatkan kesempatan yang baik dalam belajar, dengan kemampuan yang cukup baik, namun tidak menunjukkan prestasi yang cukup dan baik dalam belajar dan ada pula siswa yang sangat bersungguh- sungguh dalam belajar dengan kemampuan yang kurangdanprestasi belajarnya tetap tetap saja kurang.Hal ini menunjukkan bahwa terdapat hambatan dan masalah dalam proses belajar siswa itu sendiri, baik dalam prosesnya di sekolah maupun dirumah. Oleh karena itu, guru selaku pendidik dituntut untuk selalu dapat memberikan dorongan atau motivasi kepada siswanya yang kurang bersemangat dalam belajar dan memberikan solusi terhadap permasalahan belajar yang dihadapi siswanya. Untuk mencapai hasil belajar yang baik bukanlah suatu hal yang mudah, namun ada banyak faktor yang mempengaruhi proses belajar siswa, salah satunya yaitu kecerdasan. Slameto (2013), menyatakan bahwa kecerdasan adalah kecakapan yang terdiri dari 3 jenis, yaitu kecakapanuntukmenghadapi dan menyesuaikan kedalam situasi yang baru dengan cepat dan efektif, mengetahui atau menggunakan konsep-konsep yang abstrak 


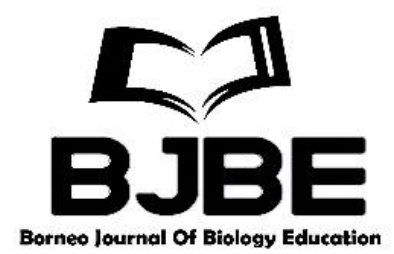

secara efektif, mengetahui relasi dan mempelajarinya dengan cepat.

Kecerdasan merupakan hal yang dimiliki oleh setiap orang, yang membedakan hanyalah tingkat kecerdasan antara siswa satu dengan yang lainnya. Kemampuan siswa dalam belajar seringkali di kaitkan dengan kemampuan intelektualnya. Pengukuran kemampuan intelektual ini ditunjukkan oleh hasil tes IQ. Hal tersebut dikarenakan siswa yang mempunyai tingkat kecerdasan yang tinggi akan lebih berhasil daripada siswa yang mempunyai tingkat kecerdasan rendah. Meskipun demikian, siswayang mempunyai tingkat kecerdasan yang tinggi belum pasti berhasil dalam belajarnya. Kosasih dan Sumarna (2014), menyatakan bahwa kecerdasan dapat di klasifikasikan menjadi 3 macam, yaitu Intelligence Quotient (IQ), Emotional Quotient (EQ), dan Spiritual Quotient $(S Q)$.Namun, yang ditelitidalampenelitianiniyaitukecerdasanemosionalatau Emotional Quotient (EQ). Goleman (2000) melalui penelitiannya mengatakan bahwa kecerdasan emosional menyumbangkan $80 \%$ dari faktor penentu kesuksesan seseorang, sedangkan $20 \%$ yang lain ditentukan oleh $I Q$.

Kecerdasan emosional erat kaitannya dengan keterampilan metakognitif. Metakognitif merupakan cara berpikir siswa dalam membangun strategi untuk memecahkan masalah. Keterampilan metakognitif adalah kemampuan siswa untuk mengontrol proses belajarnya, mulai dari tahap perencanaan, memilih strategi yang tepat sesuai masalah yang dihadapi kemudian melihat kemajuan dalam belajar dan mengoreksi jika terjadi kesalahan. Dengan keterampilan metakognitif, siswamampu mengembangkan diri, memotivasi diri sendiri, menentukan tujuan danberusaha mencapai tujuannya dengan kemandirian yang dimilikinya sehingga keberhasilan akan lebih mudah diraih. Keterampilan metakognitif sangat penting dimiliki siswa yang berkaitan dengan kemandirian dalambelajar.

Susanti (2004) menemukan bahwa dengan keterampilan metakognitif siswa mampu belajar mandiri, menumbuhkan sikapjujur,mengembangkan diri dengan menentukan tujuan dan berusaha untuk mencapai tujuan sehingga meningkatkan hasil belajar.Hasil belajar merupakan relasi atau pemekaran dari kecakapan-kecakapan potensial atau kapasitas yang dimiliki seseorang. Jadi, hasil belajar merupakan kemampuan yang diperoleh siswa setelah melalui kegiatan belajar dengan ditandai adanya perubahan tingkah laku secara keseluruhan, baik menyangkut segi kognitif, afektif maupun psikomotorik.

Permasalahan hasil belajar siswa kelas VII SMP Negeri di Nunukan diduga karena siswa cepatputus asa dan malas ketika guru memberikan soal dan tugas rumah, sehingga siswa kurang keinginan untuk berusaha memahami pelajaran. Hal tersebut menyebabkan beberapanilai siswa masih berada di bawah KKM (Kriteria Ketuntasan Minimal) yang ditetapkan oleh sekolah yaitu75. Depdikbud dalam Suryosubroto (2009) menyatakan bahwa pembelajaran dapat dikatakan berhasil apabila memenuhi kriteria ketuntasan klasikal sebesar $\geq 75 \%$ dari jumlah siswa. Solusi dari rendahnya hasil belajar siswa di sekolah yaitu proses pembelajaran harus efektif, dimana guru sebagai fasilitator dan siswa yang harus berperan lebih aktif lagi saat proses belajar mengajarberlangsung.

Sehubungan dengan uraian diatas, bahwa ada hubungan antara kecerdasan 


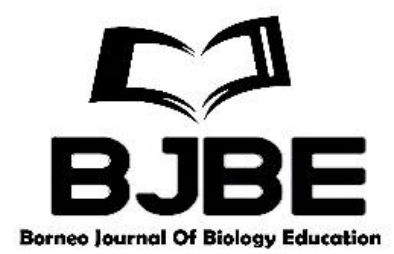

emosional dan keterampilan metakognitif terhadap hasil belajar siswa, hanya saja masih perlu pembuktian secara ilmiah. Hal inilah yang mendorong peneliti untuk mengadakan penelitian yang berjudul "Hubungan Antara Kecerdasan Emosional dan Keterampilan Metakognitif Terhadap Hasil Belajar Siswa Kelas VII SMP Negeri di Kabupaten Nunukan".

\section{Material dan metode}

Penelitian ini dilaksanakan di SMP Negeri di Kabupaten Nunukan yaitu SMP Negeri 1 Nunukan, SMP Negeri 2 Nunukan, SMP Negeri 3 Nunukan danSMPNegeri 1 Nunukan Selatan. Jenis penelitian ini adalah penelitian survey dengan menggunakan metode deskriptif korelasional (hubungan). Penelitian ini bertujuan untuk menggambarkan hubungan nyata antara variabel bebas yaitu kecerdasan emosional $\left(\mathrm{X}_{1}\right)$ dan keterampilan metakognitif $\left(\mathrm{X}_{2}\right)$ serta variabel terikat $(\mathrm{Y})$ yaitu hasil belajar siswa.Untuk mencari hubungan setiap variabel $\mathrm{X}_{1}$ dan $\mathrm{X}_{2}$ terhadap $\mathrm{Y}$ masing-masing menggunakan Uji korelasi Pearson Product Moment. Kemudian untuk mencari hubungan secara bersama- sama antara $\mathrm{X}_{1}$ dan $\mathrm{X}_{2}$ terhadap Ymenggunakan analisis regresiganda.

Instrumen yang digunakan dalam penelitian ini yaitu angket kecerdasan emosional, tes kemampuan keterampilan metakognitif (10 butir soal uraian) dan hasil belajar siswa (tes pilihan ganda yang terdiri atas 26 butir soal). Selanjutnya, data yang diperoleh dianalisis dengan uji normalitas, uji linearitas dan uji hipotesis denganmenggunakan analisis bivariat yang diinterpretasikan hubungannya berdasarkan pada kriteria di Tabel 1.

Tabel 1. InterpretasiKoefisienKorelasi

\begin{tabular}{ll}
\hline Interval Koefisien & Tingkat Hubungan \\
\hline $0,00-0,199$ & SangatRendah \\
$0,20-0,399$ & Rendah \\
$0,40-0,599$ & Sedang \\
$0,60-0,799$ & Kuat \\
$0,80-1,000$ & SangatRendah \\
\hline
\end{tabular}

(Sugiyono, 2017)

\section{Hasil dan Diskusi}

Berdasarkan hasil uji normalitas untuk kecerdasan emosional diperoleh nilai signifikansi sebesar 0,059. Sehingga nilai signifikansinya lebih $>0,05$, hal ini menunjukkan bahwa sampel berasal dari populasi yang terdistribusi normal.Sedangkan hasil uji normalitas untuk keterampilan metakognitif diperolehnilai signifikansi sebesar 0,222 . Sehingga nilai signifikansinya lebih> 0,05 , hal ini menunjukkan bahwa sampel juga berasal dari populasi yang terdistribusi normal. Demikian halnya dengan variabel hasil belajar yang juga memenuhi kriteria normal dengan nilai signifikansi sebesar 0,05 yang lebih $>0,05$. Pengujian selanjutnya yaitu uji linearitas data yang digunakan untuk mengetahui bentuk hubungan antara variabel bebas dengan variabel terikat. Untuk 


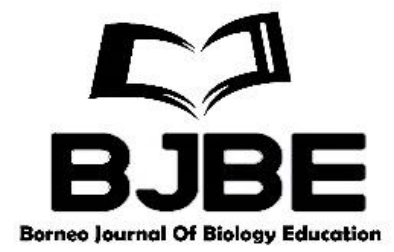

mengujidatadigunakan uji statistik menggunakan bantuan SPSS 20. Hasil dari uji SPSS kecerdasan emosional terhadap hasil belajar siswa diperoleh nilai signifikan 0,036 dimana nilai signifikansinya lebih besar dari $\alpha=0,05$, dan bedasarkan hasil dari uji SPSS keterampilan metakognitif terhadap hasil belajar siswa diperoleh nilai signifikan 0,381 dimana nilai signifikansinya lebih besar dari $\alpha=0,05$, hal ini menunjukkan bahwa sampel berasal dari populasi yang linear dan selanjutnya akan dilakukan ujihipotesis.

Uji korelasi parsial dilakukan untuk mengukur korelasi antara dua variabel bebas dengan variabel terikat dengan melihat pengaruh dari satu atau beberapa variabel lain.Berdasarkanhasil analisis data yang dilakukan, menunjukkan bahwa harga dari korelasi product moment yaitu kecerdasan emosional terhadap hasil belajar memiliki nilai signifikansi $0,185>0,05$ serta keterampilan metakognitif terhadap hasil belajar memiliki nilai signifikansi $0,042<0,05$, yang berarti tidakterdapatkorelasi antara kecerdasan emosional terhadap hasil belajar siswa dan terdapat korelasi antara keterampilan metakognitif terhadap hasil belajar siswa.Hasil ringkasan uji regresi linier gandadapatdilihat pada tabel 2 berikut.

Tabel 2. Ringkasan Hasil Uji Regresi Linier Ganda

\begin{tabular}{lllll}
\hline Model & R & R Square & $\begin{array}{l}\text { Adjusted R } \\
\text { Square }\end{array}$ & $\begin{array}{l}\text { Std. error of } \\
\text { the Estimate }\end{array}$ \\
\hline 1 & $0,164^{\mathrm{a}}$ &, 027 & 0,019 & 12,253 \\
\hline
\end{tabular}

a. Predictors: (Constant), KeterampilanMetakognitif, KecerdasanEmosional

Model summary ini digunakan untuk melihat $R$ square dalam menghitung sumbangan efektif dan sumbangan relatif pada variabel independen terhadap variabel dependen, dimana $R$ square merupakan sumbangan simultan sebesar 0,027 atau 2,7\%. Hal ini menunjukkan bahwa sumbangan pengaruh variabel independen terhadap variabel dependen sebesar 2,7\% sedangkan Adjust $R$ Squareadalah nilai $R$ square yag telah disesuaikan dan nilai ini selalu lebihkecil dari $R$ square.

Berdasarkan hasil analisis data menggunakan regresi berganda, hubungan antara kecerdasan emosional, keterampilan metakognitif terhadap hasil belajar siswa didapatkan nilai signifikansi $0,038<0,05$. Dengan demikian dapat disimpulkan bahwa hipotesis diterima yang berarti terdapat hubungan antara kecerdasan emosional, keterampilan metakognitif terhadap hasil belajar siswa. Hasil tersebut dapat dilihat pada tabel 3 berikut.

Tabel3. Uji Anova (Anova $\left.{ }^{a}\right)$

\begin{tabular}{lllllll}
\hline \multicolumn{2}{l}{ Model } & $\begin{array}{l}\text { Sum of } \\
\text { Squares }\end{array}$ & df & $\begin{array}{l}\text { Mean } \\
\text { Square }\end{array}$ & F & Sig. \\
\hline 1 & Regression & 995,639 & 2 & 497,820 & 3,316 & $0,038^{\text {b }}$ \\
& Residual & 35880,708 & 239 & 150,128 & & \\
& Total & 36876,347 & 241 & & & \\
\hline
\end{tabular}

a. Dependent Variable: Hasil BelajarSiswa

b. Predictors: (Constant), Keterampilan Metakognitif, Kecerdasan Emosional 
Hasil uji regresi berganda diperoleh persamaanregresi yaitu $\mathrm{Y}=74,695+(-$ 0,094) $X_{1}+(-0,092) X_{2}$ dengan koefisien korelasi kecerdasan emosional sebesar 0,122 (tidak memiliki hubungan) dan keterampilan metakognitif 0,029 (memiliki hubungan). Pengaruh $\mathrm{X}_{1}$ dan $\mathrm{X}_{2}$ terhadapYadalah $2,7 \%$ dilihat dari $\mathrm{R}_{\text {square. Untuk variabel }} \mathrm{X}_{1}$ (Kecerdasan emosional) sumbangan efektifnya adalah 0,9\%. dan $\mathrm{X}_{2}$ (keterampilan metakognitif) sumbangan efektifnya adalah 1,3\%. hal inimenunjukkanbahwa kecerdasan emosional dan keterampilan metakognitif tidak memiliki hubungan sama sekali.Berbedahalnyadengansumbanganrelatif, didapatkan sumbangan relative dari tiap variabel dimana sumbangan relatif untuk $\mathrm{X}_{1}$ (kecerdasan emosional) adalah $34 \%$, sedangkan sumbangan relatif untuk $\mathrm{X}_{2}$ (Keterampilan metakognitif) sebesar $48 \%$. Hal ini menunjukkan bahwa sumbangan relatif yang diberikan tidak linier.

Berdasarkan hasil analisis indikator pengukuran kecerdasan emosional menunjukkan bahwa siswa tinggi pada indikator membina hubungan dengan persentase $19,36 \%$, mengelola emosi $20,73 \%$, memotivasi diri $21,09 \%$ dan rendah pada indikator empati dengan persentase $19,16 \%$ dan mengenali emosi dengan persentase $19,23 \%$. Selain itu, yang membuat tidak adanya hubungan antara kecerdasan emosional terhadap hasil belajar yaitu dilihat dari hasil perolehan besarnya sumbangan efektif kecerdasan emosional terhadap hasil belajar sebesar 0,9\% dan besarnya sumbangan relatif kecerdasan emosional terhadap hasil belajar sebesar 34\%. Menurut Goleman (2009), ada beberapa faktor yangmempengaruhi kecerdasan emosional individu, yaitu lingkungan keluarga dimana kehidupan keluarga merupakan sekolah pertama dalam mempelajari emosi. Peran serta orang tua sangat dibutuhkan karena orang tua adalah subyek pertama yang perilakunya diidentifikasi yang pada akhirnya akan menjadi bagian dari kepribadian anak. Kecerdasan emosional ini dapat diajarkan pada saat anak masih bayi dengan contoh-contoh ekspresi. Hal ini sesuai dengan hasil data dari penelitian yaitu rendahnya mengenali emosi diri sendiri yang memiliki nilai persentase 19,23\% dan empati yang memiliki nilai sebesar 19,16\%.Rendahnyadalam mengenali emosi diri dan empati akan menjadikan anak tidak mudah menangani dan menenangkan diri dalam menghadapi masalah sehingga anak tidak dapat berkonsentrasi dengan baik dan memiliki banyak masalah tingkah laku seperti tingkah laku kasar dannegatif.Selanjutnya, lingkungan non keluarga dalam hal ini adalah lingkungan masyarakat dan lingkungan penduduk. Berdasarkan hasil data penelitian didapatkan rendahnya persentase pada indikator membina hubungan yaitu dengan persentase 19,36\%.Rendahnya dalam membina hubungan dapat menjadikan anak sulit untuk bersosialisasi dan mengenal lingkungan sekitar. Kecerdasan emosi ini berkembang sejalan dengan perkembangan fisikdanmental anak. Pembelajaran ini biasanya ditunjukkan dalam aktivitas bermain anak seperti bermain peran. Anak berperan sebagai individu di luar dirinya dengan emosi yang menyertainya sehingga anak akan mulai belajar mengerti keadaan orang lain. Hal tersebutdidukung oleh penelitian dari Iman Firmansyah (2010) yang meneliti tentang pengaruh tingkat kecerdasan emosional terhadap hasil belajar siswa SMA Triguana Utama Ciputat. Dari penelitian tersebut, 


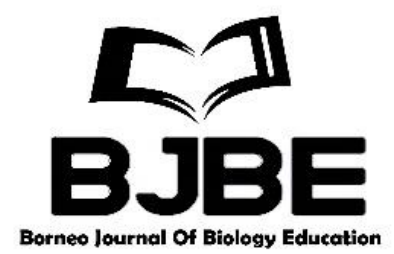

didapatkan hasil penghitungan uji korelasi dengan menggunakan teknik Pearson's product-moment dihasilkan nilai koefisien korelasi pengaruh tingkat kecerdasan emosional terhadap prestasi belajar siswa SMA Triguana Utama Ciputat adalah0,210dengannilaip $=0,294(\mathrm{p}>0,05)$. Sementara nilai $\mathrm{r}$ tabel pada taraf signifikansi 5\% dengan $\mathrm{N} 27$ adalah sebesar 0,318. Karena nilai $\mathrm{r}$ hitung yang dapat 0,210 dengan demikian hipotesis alternatif $\left(\mathrm{H}_{0}\right)$ yang menyatakan ada pengaruh tingkat kecerdasan emosional terhadap prestasi belajar siswa SMA Triguana Utama Ciputat di tolak, yang berarti tinggi-rendahnya kecerdasan emosional siswa tidak mempengaruhi prestasi belajar siswa tersebut. Hal ini disebabkan oleh faktor luar yang lebih mempengaruhi seperti minat, bakat maupun pribadi dan sikap guru.

Berbagai penelitian dalam bidang psikologi anak telah membuktikan bahwa anakanak yang memiliki kecerdasan emosi yang tinggi adalah anak-anak yang bahagia, percaya diri, popular, dan lebih sukses di sekolah. Mereka lebih mampu menguasai gejolak emosi, menjalin hubungan yang manis dengan orang lain, dapat mengelola stress, dan memiliki kesehatan mental yang baik (Mashar, 2011). Menurut Daniel Goleman, IQ hanya mendukung sekitar 20\% yangmenentukan suatu keberhasilan, $80 \%$ sisanya berasal dari faktor lain, termasuk kecerdasan emosional.

Variabel $\mathrm{X}_{2}$ (Keterampilan Metakognitif) memiliki koefisien korelasi yaitu sebesar 0,029 yang artinya terdapat hubungan antara keterampilan metakognitif terhadap hasil belajar siswa. Kemampuansiswa dalam melakukan perencanaan, pemantauan dan evaluasi terhadap hasil belajar siswa menunjukkan hasil yang positif. Hasil penelitian ini menunjukkan bahwa hubungan antara keterampilan metakognitif terhadap hasil belajar siswa SMP Negeri di Kabupaten Nunukan berada pada kategori yang remdaj. Kecenderungan seseorang untuk belajar sangat beragam dan dalam menyerap informasi maupun mengolah informasi tersebut berbeda-beda setiap orang. Hal tersebut menunjukkan adanya kecenderungan belajar pada setiap manusia. Hubungan antara keterampilan metakognitif terhadap hasil belajar yang rendah dapat disebabkan oleh faktor lain diluar variabelpenelitian.Flavell (1979) menjelaskan bahwa metakognisi terdiri dari pengetahuan metakognitif dan pengalamanmetakognitif. Pengetahuan metakognitif terdiri dari 3 kategori berikut; (1) pengetahuan tentang diri sendiri, (2) pengetahuan dalam mempelajari tugas, dan (3) pengetahuan dalam strategi. Pengalaman metakognitif mencakup penggunaan strategi metakognitif atau regulasi metakognitif. Adanya pengalaman metakognitif dapat membantu siswa dalam meregulasi proses pembelajaran, merancang dan memonitor aktivitas kognitifsertamembandingkan hasil dari aktivitas kognitif tersebut. Dengan demikian, apabila siswa sudah memiliki keterampilan metakognitif yang baik, siswa tersebut mampu memonitor aspek kognitifnya sendiri sehingga hasil belajar akan meningkat. Hasil diatas didukung dengan hasil penelitian oleh Basith (2011) maupun Chikmiyah dan Bambang (2012), korelasi antara keterampilan metakognitif terhadap hasil belajar kognitif pada penerapan strategi pembelajaran TPS pada penelitian ini tergolong sedang. Hal ini terlihat dari sumbangan relatif yang diberikan keterampilan metakognitif terhadap hasil belajar hanya sebesar 


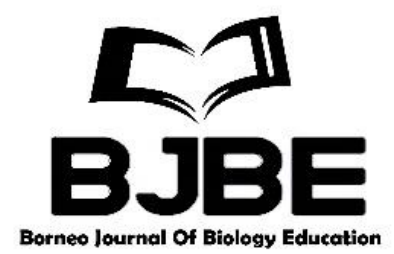

$32,5 \%$, serta koefisien korelasi 0,570. Koefisien korelasi tersebut jika dibandingkan dengan kriteria interpretasi koefisien korelasi termasuk dalam kategorisedang.

\section{Kesimpulan}

Hal yang dapat disimpulkan dari penelitian ini yaitu tidak terdapat hubungan yang signifikan antara kecerdasan emosional $\left(\mathrm{X}_{1}\right)$ terhadap hasil belajar siswa $(\mathrm{Y})$. Selanjutnya besaran sumbangan efektif pada variabel $\mathrm{X}_{1}$ sebesar $0,9 \%$ dan keterampilan metakognitif $\left(\mathrm{X}_{2}\right)$ sebesar 1,3\%. Hal ini menunjukkan bahwa keterampilan metakognitif memberikan kontribusi yang rendah terhadap hasil belajar siswa sehingga terdapat faktor lain diluar variabel penelitian. Besaran sumbangan relatif pada variabel $\mathrm{X}_{1}$ sebesar $34 \%$ dan $\mathrm{X}_{2}$ sebesar $48 \%$. Hal menunjukkan bahwa terdapat faktor lain yang mempengaruhi. Faktor tersebut dibagi menjadi 2, yaitu faktor internal dan eksternal. Faktor internal sendiri terdiri dari minat, motivasi dan cara belajarnya serta faktor ekternal terdiri dari partisipasi orang tua, guru serta fasilitas belajar yang memadai.

\section{Daftar Pustaka}

Anam. (2014). Efektifitas Dan Pengaruh Model PembelajaranInkuiri Pada Pembelajaran IPA di Sekolah Dasar. E-journal Mimbar Sekolah Dasar STKIP Sebelas April Sumedang 2 (1)

Arikunto, S. (2010). Prosedur Penelitian: Suatu Pendekatan Praktek. Jakarta: PT. Rineka Cipta.

Aunurrahman (2014). Belajar dan Pembelajaran. Bandung: Alfabeta

Basith, A. (2011). Hubungan Keterampilan Metakognitif dan Hasil Belajar Mata pelajaran IPA pada Siswa Kelas IV SD dengan StrategiP embelajaran Jigsaw dan Think Pair Share (TPS). Skripsi tidak diterbitkan. Malang: JurusanBiologi FMIPAUM.

Budiningsih, C. A. (2005). Belajar dan Pembelajaran. Jakarta: PT RinekaCipta

Chikmiyah, C., \& Bambang S. (2012). Relationship Between Metacognitive Knowledge And Student Learning Outcomes Through Cooperative Learning Model Type Think Pair Share On Buffer Solution Matter. Unesa Journal of Chemical Education, 1 (1):55-61, (Online), (http://ejournal. unesa.ac.id/ article/ 202/36/articl e.pdf), diakses 20 Agustus 2019.

Corebima, A. D. (2005). Pengukuran Kemampuan Berpikir Pada Pembelajaran Biologi. Makalah disajikan pada Seminar Dies Ke41 Universitas Negeri Yogyakarta dengan Tema Hasil Penelitian Tentang Evaluasi Hasil Belajar Serta Pengelolaannya, Yogyakarta 14-15 Mei2005. 
Corebima, A. D. 2006. Pembelajaran Biologi Yang Memberdayakan Kemampuan Berpikir Siswa. Makalah disajikan dalam Pelatihan Strategi Metakognitif pada Pembelajaran Biologi untuk Guru-guru Biologi SMA, Lembaga Pengabdian Kepada Masyarakat (LPKM) UNPAR, Palangkaraya, 23Agustus 2006.

Daud, F. (2012). Pengaruh Kecerdasan Emosional (EQ) dan Motivasi Belajar Terhadap Hasil Belajar Biologi Siswa SMA 3 Negeri Kota Palopo. Jurnal Pendidikan dan Pembelajaran 19 (2).

Desmita. (2010). Psikologi Perkembangan Peserta Didik. Bandung: PT. Remaja Rosda Karya

Dimyati \& Mudjiono. (2009). Belajar dan Pembelajaran. Jakarta: PT. Rineka Cipta

Djamarah. (2008). PsikologiBelajar. Jakarta: Rineka Cipta

Fauziyah, D.R., Corebima, A.D., dan Zubaidah, S. (2013). Hubungan Keterampilan Metakognitif terhadap Hasil Belajar Biologi dan Retensi Siswa Kelas X dengan Penerapan Strategi Pembelajaran Think Pair Share di SMA Negeri 6. Artikel Publikasi. Universitas Negeri Malang 